\title{
Research Review and Prospect of China English
}

\author{
Jinhua Zhang \\ Correspondence: Jinhua Zhang, School of Foreign Languages, Xi'an Aeronautical University, Xi'an, China. \\ E-mail: zjhclara@163.com
}

Received: Aug. 22, 2020

Accepted: Sep. 20, $2020 \quad$ Online Published: Sep. 28, 2020

doi:10.5430/elr.v9n3p50

URL: https://doi.org/10.5430/elr.v9n3p50

\begin{abstract}
The paper has reviewed the research of China English. It has revealed the origin and controversy about China English and then it reviewed the majority of research about China English to present the development of it. After that, the paper presented the definition and the research gap it faces. Through the research review, it is found that the micro studies about the features of China English still need to be explored in the future.
\end{abstract}

Keywords: China English, research review, micro studies

\section{Background of the Study}

English, as the world lingua franca, is playing an increasingly important role in international communication. Crystal (2001) noted that two thirds of prints are published in English, 90\% scientific articles are written in this language and it also enjoys the right of priority in the language choice of international agreement and contracts. Currently much more attention has been paid to English and English education. In China, people learn English as a second language and how to learn it well and how to use it have interested both language learners and teachers. In the past, we learned English by imitating Standard English, and we tried our best to learn British or American varieties of English. However, language is changing all the time, which keeps changing with the development of the society. English has changed a lot with the time going on.

\subsection{Origin of China English}

English, nowadays, has developed to the stage of world English (Hu, 2012). It is used on all continents (Zhang, 2019). Before Second World War, most linguists thought English used by the higher class in the Britain can be regarded as the only Standard English. After the Second World War, American English is also recognized as a kind of Standard English with the development of America. At present, a growing number of countries use English. English has become the most widely used second language (Oxford, 2013).

With the migrations of English-speaking populations, colonization, and the use of English in the trade and commerce, English is localized in variety of districts. If you are abroad, English is likely to be somewhat different from the way you speak it (Schneider, 2013). British English and American English are not only standards for it but two varieties of English. English has been influenced in different cultural backgrounds and it has demonstrated various features in different cultures.

Gradually, when English is spread to different countries and is influenced by different cultures, history and politics, new varieties come into being. English, in China, has changed a lot with the influence of Chinese culture and history. Thus, English used by Chinese with Chinese characteristics is considered to be China English.

\subsection{Controversy about China English}

Within a period of time, many scholars have explored whether there is China English (Sun, 1989; Rong, 1991). Sun (1989) held the idea that it was too early to regard English used by Chinese at that time as a variety in the linguistics. Rong (1991) admitted the objective existence of China English and gave the definition of it. Han (2007) reviewed the research about China English and summarized it into several research stages. The discussion about China English can date back to the 1960s. At that time, scholars regarded the language phenomenon with Chinese characteristics as the language errors. When it comes to the 1990s, more and more scholars realized that China English is a member of World English (Han, 2007). As Wang and Jenkins (2016, p.42) states, "since the start of the 21 st century, English has become a widely used language accessible to many users from China". Thus, nowadays China English has become a social issue with the global attention (Han, 2007). 
As accepted by many scholars, China English can be defined as English used by Chinese with the center of Standard English and with Chinese characteristics in China (Rong, 1991; Hu, 2008). In their views, China English is a variety of the world English. However, the characteristics of China English still need to be explored. Since English is used in China, it is inevitable to be influenced by Chinese culture, so English used by local people in China is China English. Many scholars have studied the characteristics of China English. They intend to figure out that to what extent China English is influenced by Chinese culture.

\section{Definition of China English}

The only standard for English has been doubted for a long time. Jiang and Du (2003) reported that there is a larger number of non-native English users compared with native English users, so it is impractical to insist the only standard of English. Zeng (2008) noted that with the deepening of globalization, the standard diversification is the tendency of English development. It is unavoidable to be localized due to its wide spread and culture contact. Thus, many varieties of English have come into being. Used by an increasing number of countries, English does not belong to a certain country but becomes a tool to communicate with others. It is not only the language of America and Britain but also the world language. China English is the inevitable product in this period. As a localized variety of English, China English has some certain features which differentiate it from other English varieties.

Many scholars have devoted to studying China English for a long time. China English was first raised by Ge Chuangui in 1980. The famous British group DEMOS has admitted that China English is a variety of world English in its report As You Like it: Catching up in an Age of Global English (Zeng, 2008). Besides that, many scholars defined China English with their own research. Main points of the definition are as follows: English used by local Chinese is China English; China English sets Standard English as the norm; China English can be used to express some certain culture and concepts in China.

Zhan, Li, and Fu (2015) have acknowledged the influence of Chinese way of thinking on English. China English, as a variety of English, is the result of internationalization and localization of the language, which is influenced by Chinese way of thinking (Zhan, Li \& Fu, 2015). Kachru (1985) proposed that native English users seem to lose the monopoly right for controlling the standard of English. It is inevitable to lead to the variation of English because of the language contact. The internationalization of English leads to the extensive localization. The essence of the culture is the certain value and the way of thinking. The culture, historical background and cultural tradition vary from each nation, thus the way of thinking is different. Therefore, English in China has been influenced a lot by Chinese culture and gradually China English has been formed. China English is the product of English internationalization and it is a localized English variety with Chinese characteristics. However, the emergence of China English has experienced a long process.

Before the Second World War, most linguists agreed that only British English can be regarded as the Standard English. London English and English that used by British higher class are regarded as the Standard English. After the Second World War, with the improvement of American comprehensive power, American English is considered to be another Standard English. Nowadays, more and more countries use English as their native language, second language and foreign language. English has become a world language but does not belong to one or two countries any more so British English and American English are not the only two standards for it but two English varieties. The Standard English does not exist while those that follow the common rules of English and those that can be accepted by English countries can be called normative English ( $\mathrm{Li}, 1993)$. The language is used in a certain environment so it is impossible to avoid the influence of English localization. Therefore, English used in China has many Chinese characteristics. Ge (1980) proposed that the specialized expression of English in China is called China English.

Li (1993) has distinguished China English from Chinglish and he has also defined both of them. He (2016) reported that China English should follow the normative English and express the specialized issue in all the fields of China but without the interference of mother tongue. Li (1993) has distinguished China English from Chinglish and then proposed that China English is normative English but Chinglish is an abnormal language phenomenon. Later, many scholars have revised the definition of China English and have raised some suggestions about revision based on that (Zhang, 1995; Xie, 1995). Besides this, Li (1993) revised the definition of China English from lexicon, syntax and discourse and admitted the existence of China English.

\section{Previous Research and Research Prospect on China English}

\subsection{Previous Research on China English}

The research on China English has already been a hot issue for sociolinguistics, linguistics and language teaching 
(Wu, 2014). The research on China English starts from the 1980s. Ge (1980) proposed "China English" for the first time in 1980. After that, many scholars have revised the definition of China English with the understanding toward it advancing (Li, 1993; Zhang, 1995; Xie, 1995). Research on China English can be divided into the research from the macro aspects and that from the micro aspects.

In the macro aspect, research in China English is conducted in the frame of world English. At the beginning, scholars realized the characteristics of Chinese appearing in English and then they tried to correct such non-standard English (Han, 2007). They held the view that British English and American English are the only standards and English with Chinese characteristics can not be accepted. With the universalization of English, standard diversity of English is admitted by more and more people. The new concept of China English is raised. In 1980, Ge (1980) proposed China English for the first time and he emphasized that when we use English in China there must be something with Chinese characteristics to express. Meanwhile, several papers were published to study the related issue. Sun (1989) first raised the situation of English as a localized variety in China. Rong (1991) first distinguished China English from learners' language errors, which laid a solid foundation for related research about China English. Some studies explored how much influence globalization has brought to China English. In this aspect, China English is a necessary product in the spreading of English and it is a variety of English, which enjoys the equal status with British English and American English. Zhan, Li and Fu (2015) discussed the essence, origin and development of China English. Hu (2008) has studied China English from the functional perspective. His study employs the functional theory to reveal the essence of China English and it also analyzes three functions China English has played. It explains language phenomena from functionalism and reveals that the development of language is relevant with social and cultural life.

While in the micro aspect, China English has its own features because of the influence of Chinese culture and history. Wu (2014) reported that the study on China English put more emphases on language level but fewer emphases on culture level. Thus it's necessary for us to combine the study on language and the study on culture to explore the characteristics of China English. This study explores the features of China English and it aims to construct a descriptive frame for the features of localized English in China. Pan (2020) analyzed the characteristics of China English from the politics and culture aspects. She distinguished China English from Chinese English and admitted the significant role China English plays in the spread of Chinese culture.

\subsection{Research Prospect on China English}

Nowadays, more qualitative studies but fewer quantitative studies are conducted. And also, there are more macro studies but fewer micro studies. In this condition, we cannot get a comprehensive overview about China English. Therefore, in the future we need to conduct more empirical research on China English to explore its localized features from micro aspect. More studies should be conducted from both language and culture level.

\section{References}

Crystal, D. (2001). English as a Global Language (vol. 2, pp. 60-61). Beijing: Foreign Language Teaching and Research Press.

Ge, C. G. (1980). On Chinese to English translation. Chinese Translators Journal, (02), 1-8.

Han L. (2007). An analysis on current research situation of Chinglish. Foreign Languages and Their Teaching, (10), 28-32. https://doi.org/10.13458/j.cnki.flatt.003488

He, H. (2016). An empirical study of identity construction via advising discourse in International English journal articles. Foreign Language Learning Theory and Practice, 01, 34-40+54.

Hu, X. L. (2008). Studies of China English: review and prospects. Foreign Languages in China, (2), 27-30+35. https://doi.org/10.13564/j.cnki.issn.1672-9382.2008.02.019

$\mathrm{Hu}, \mathrm{X}$. L. (2012). The enlightenment of the development of world English varieties on English teaching. Foreign Languages and Their Teaching, 6, 44-48. https://doi.org/10.13458/j.cnki.flatt.003851

Jiang, Y. J.\& Du, R. Q. (2003). Questions about "China English" -- a response to the article "questioning China English". Foreign Language Education, (1), 27-35. https://doi.org/0.16362/j.cnki.cn61-1023/h.2003.01.015

Kachru, B. B. (1985). Standards, codification and sociolinguistic realism: The English language in the outer circle. In R. Quirk \& H. Widdowson (Eds.). English in the world: Teaching and learning the language and literatures. Cambridge: Cambridge University Press.

Li, W. Z. (1993). China English and Chinglish. Foreign Language Teaching and Research, (04), 18-24+80.

Oxford. (2013). Oxford Dictionaries Online. Retrieved from http://www.Askoxford.com 
Pan, Y. T. (2020). New features of "China English" from the perspective of eco translation --Taking Xi Jinping's English translation of governing the country (second volume) as an example. Journal of Jiamusi Vocational Institute, 36(07), 106-107.

Rong, P. (1991). China is an objective existence. Journal of PLA University of Foreign Languages, (01), 18-24+80.

Schneider, E. W. (2013). English Around the World. Cambridge University Press.

Sun, L. (1989). A study of English national variants and English in China. Journal of Foreign Languages, (2), 17-23.

Wang, Y., \& Jenkins, J. (2016). Nativeness and intelligibility: Impacts of intercultural experience through English as a lingua franca on Chinese speakers' language attitudes. Chinese Journal of Applied Linguistics (Quarterly), 39(1), 38-58. https://doi.org/10.1515/cjal-2016-0003

Wu, J. H. (2014). Review and prospect: Reflection on the current situation of China English research. Contemporary Foreign Languages Studies, 5, 24-28.

Xie, Z. J. (1995). China English: a disturbing variant in intercultural communication. Modern Foreign Languages, (04), 7-11+72. https://doi.org/10.16482/j.sdwy37-1026.1994.z1.026

Yang, N. R. \& Yan, H. (2002). Aspects and features of China English. Journal of Xidian University (Social Science Edition), (2), 13-15. https://doi.org/10.16348/j.cnki.cn61-1336/c.2002.02.019

Zeng, T. (2008). The development of China English and its effects on English teaching. Education and Teaching Research, 22(1), 68-70+75. https://doi.org/10.13627/j.cnki.cdjy.2008.01.015

Zhan, J., Li, F.\& Fu, H. M. (2015). Understanding Chinese English: In the perspective of language variation theory. Jilin University Journal Social Sciences Edition, 55(3), 163-170. https://doi.org/10.15939/j.jujsse.2015.03.020

Zhang, J. H. (2019). Some views about standard English. English Language and Literature Studies, 9(4), 94-98. https://doi.org/10.5539/ells.v9n4p94

Zhang, P. C. (1995). The international or intranational use of English and its English varieties. Modern Foreign Languages, (03), 16-21+72.

\section{Copyrights}

Copyright for this article is retained by the author(s), with first publication rights granted to the journal.

This is an open-access article distributed under the terms and conditions of the Creative Commons Attribution license (http://creativecommons.org/licenses/by/4.0/). 